\title{
THE 'ISLAMIC WOMEN'S' MOVEMENT: TRANSITION FROM THE PRIVATE DOMAIN TO THE PUBLIC SPHERE
}

\author{
Ömer Çaha*
}

\begin{abstract}
This article emphasises the development of the Muslim women's movement in Turkey. It traces the historical roots of this movement as well as its evolution towards two different understandings of women. It is clearly seen that there exist two main approaches to the role of women among Islamic groups: while the traditional Islamic understanding strives to maintain women's traditional roles notwithstanding that it advocates the right to benefit from modern education, another understanding challenges this and tries to ensure women's existence on a 'womanly' base in the public life. The author attempts also to depict the story of how Muslim women have attempted to be articulated in the public sphere, their 50 -year struggle to achieve that goal, as well as the discourses, values and symbols that have generally been centred on the 'headscarf debates'.
\end{abstract}

\section{Introduction}

This article emphasises the development of the Muslim women's movement in Turkey. It traces the historical roots of this movement as well as its evolution towards two different understandings of women. It is clearly seen that there exist two main approaches to the role of women among Islamic groups: while the traditional Islamic understanding strives to maintain women's traditional role notwithstanding that it advocates the right to benefit from modern education, another understanding challenges this and tries to ensure women's existence on a 'womanly' base in the public life. In this article, I depict how 'Islamic women' attempted to express themselves in the public sphere, over 50 years, as well as the discourses, values and symbols that have generally been centred on the headscarf debates, and how the 'women's movement' developed on the basis of this issue.

* Ömer Çaha is a Professor in the Department of Public Administration at Fatih University, Istanbul, Turkey. 


\section{The Rise of Democratic Public Life and 'Islamic Women'}

It is generally accepted that in the early decades of the Turkish republican regime, established after 1923, women started to serve the regime not only in public institutions individually, but also through various organisations. During the single party regime, which continued until 1950, women were directed to serve the regime mostly under the banner of the Republican People's Party (CHP). In the 1950s, when multiparty life started, we observe that the political and ideological separation which emerged in Turkey also triggered women. Islamic groups that got rid of oppression through liberal policies pursued by the Democratic Party gradually started to be a part of public life and interested in politics. The attendance in modern educational institutions and their interest in politics would lay the foundations of the separation between the 'cultural' Islam and the 'political' Islam in the following years. The importance of 'science', or 'wisdom' as it is used in the Islamic literature, has been emphasised in both groups and the idea that "science is a religious obligation for men and women" has rapidly become popular among them. ${ }^{1}$ In particular, the translation of Islamic sources like the Qur'ān, the ahādìth of the Prophet, and works on Islamic jurisprudence ( $f q h$ ) into Turkish has enabled Muslim groups to get acquainted with the essential religious resources, and to further comprehend the importance of science and education by benefiting more from Islamic resources.

The religious atmosphere ascending in the country has expectedly found some women in the public sphere and modern institutions. The headscarf was first seen at university in the early 1950 s. $^{2}$ Fevziye Nuroğlu, who started to wear the headscarf at university in the early 1960s, recounts that in total there were four students with headscarves attending Turkish educational institutions in those days. ${ }^{3}$ Nuroğlu states that modern educational institutions and the well-developed districts of modern cities like Istanbul were not yet familiar, at that time, with the headscarf and did not show tolerance towards students like her. Until then, headscarf and traditional dress had been considered as symbols identified with peasantry, backwardness and ignorance. Although no regulation was made about women's dress during the single-party period, the struggle against the traditional veil such as çarşaf (a traditional dress covering a woman's whole body) laid the foundations of an elitist attitude and perspective. Women in schools and public institutions and even those working in the tobacco, soap, and textile industries were 'modern looking' women freed from traditional dress. While women employed in public institutions as officials were required to dress up 'modern', other women working as cleaners or tea servants were asked to cover their heads. ${ }^{4}$ The message delivered through this policy was that the women working in white-collar jobs had been modernised by getting rid of their veils while women doing errands remained traditional. 
Veiled female students in modern institutions were perceived to be a challenge to the elitist official policy of the state and were punished harshly. For instance, Gülsen Ataseven graduated from a faculty of medicine as the top student in 1964. However, because she was wearing a headscarf, her degree was taken away and given to the second best student. Although there was a big difference between the two students' scores, the university management did not deem Gülsen Ataseven to be the 'appropriate' top student. Later, veiled women in various institutions came to be punished in similar ways. The punitive attitude of the state towards the headscarf naturally created a reaction among traditional conservative groups.

The incident that made this reaction visible in the public sphere took place in Ankara University Faculty of Divinity. In 1968, the dismissal of Hatice Babacan, a student in the Faculty of Divinity, brought a strong reaction from Islamic groups. Hatice Babacan immediately became the symbol of Islamic groups. The issue was covered by the publications of these groups, a boycott campaign started in front of the Faculty of Divinity and the boycott became a current issue in parliament. The dean, Neşat Çağatay, was obliged to resign from his office as a result of the slogans "resign, dean". The next case involved the lawyer Emine Aykenar in 1972. After she declared that she would not uncover her head as a 'requirement of her faith' in a trial in the Council of State she was dismissed from her profession by the Head of the Ankara Bar Association. In brief, the harsh punishment for religious veiling among individuals during the 1960 s by the state created a social interest in - and even a resistance to - such politics.

The 1960s were the years when Şule Yüksel Şenler occupied the stage among Islamic circles and initiated the process of a radical break from the 'official' way of dressing. SSenler, who had been a modern townswoman and a columnist for the Yeni Istiklal newspaper since the mid-1960s, started to wear the veil by developing a 'stylish' and 'elegant' dressing style. She began a struggle to popularise veiling through five years of nationwide conferences in which she spoke of her cause and the importance of veiling to women. The headscarf, which Şenler tried to popularise, created a strong reaction in the ruling elite and the secular media. The 'stylish' and 'elegant' style of headscarf, to be distinguished from the traditional style, was talked down by being named as şulebaşı (head of Şule). This naming would be transformed into turban by the same groups in the 1980s.

Şenler's beliefs left an indelible impression on young girls and religious women, and the headscarf rapidly became popular in the streets. This trend became so notable that the then President of the Republic, Cevdet Sunay, stated that "the pioneers of veiled women in the streets will get their deserts". ${ }^{6}$ Senler tried to popularise her cause through her book The Tranquil Street (Huzur sokağı) which has become one of the most-read novels not only by women but also by men after the 1970s. Şenler is a notable figure whose achievement was to put the 'issue of the woman' on the 
agenda of Islamic groups in the 1960s and 70s. ${ }^{7}$ In addition, interest in the 'issue of the woman' has increased among theologians since the mid-1960s and various publications have appeared on the subject. Hayrettin Karaman's book Woman and Family in Islam (İslam'da kadın ve aile) and Bekir Topaloğlu's Woman in Islam (Islam'da kadın) were intended as a response to the West and other civilisations and to prove how 'perfect' Islam is supposed to be and what 'rights' it provides women with. These books cover the necessity of women to be 'protected' through values such as veil, modesty, chastity, and morality, and the importance of this protection for the social order. ${ }^{8}$

In the 1970s, the issues of veiled woman and woman's education became of interest to ordinary citizens of various religious communities and political Islamic groups. Şule Yüksel Şenler set a significant example on this issue with her identity of 'educated woman'. On the other hand, conservative fathers acquired the opportunity to school their daughters when girls' classrooms were launched in imam hatip schools (government-run religious schools). The Qur'ān classes and imam hatip schools were important instruments for the schooling of daughters of conservative families in the 1970s. ${ }^{9}$

It was after the 1980s that real momentum was experienced among Islamic circles about the 'issue' of women. The mentality-change experienced by Turkey after 1980 in many fields was naturally reflected in the social values. As a consequence of liberal politics initiated by then Prime Minister Turgut Özal, Turkish society made a rapid transition towards modernisation. The blasting point of the social modernisation was and still is observed in the rising interest in getting modern education. After the 1980 s, education started to be perceived as an important necessity by all parts of society. The policy to spread English-based education opportunities to the remotest corners of Anatolia through Anatolian High Schools (Anadolu Liseleri) naturally created the consequence that the demand for modern education took rural people into its circle. Conservative fathers, who had sent their daughters to Qur'ān classes and imam hatip schools in the 1970s, started to send their daughters to high schools and universities offering modern education. Especially with the dissemination of university preparatory courses throughout the country, it has become possible for students from small towns to get into universities. In this respect, it can be argued that university preparatory courses served for a very important social mobilisation. As a consequence of all these factors, a hitherto unobserved number of veiled young women started to appear in educational institutions, streets, and workplaces.

The modernisation policies in the country, on the other hand, paved the way for what has been referred to as 'Islamic Calvinism'. ${ }^{10}$ The flow of capital to the periphery and to the grassroots, the opening of Turkey to the world markets, Özal's encouragement of Anatolian businessmen to enter the global markets, and the emerging business opportunities due to the collapse of the Soviet Union all played 
important roles in the emergence of an Islamic bourgeoisie or a Muslim middle class. Religious values and symbols, which had been popular among the lower classes until the 1960s, were increasingly embraced by people from middle and even high classes. The 'headscarf' as a religious symbol used by women started to be visible in modern cities, modern neighbourhoods, holiday resorts, and even on podiums. Veiling fashion shows, staged in Turkey from time to time, demonstrate that an economic market had emerged on headscarf and veiling. ${ }^{11}$

While the conservative-religious woman tries to be involved in modern institutions, she pursues the goal of preserving her veil as a traditional religious value. She carries out the modern practice of life oriented towards education, trade, holiday and entertainment in traditional dresses with modern patterns. In other words, the religious woman experiences modern values within traditional forms. The turban, which is more stylish compared to çarşaf and the traditional headscarf, has become a symbol of the synthesis of "the traditional and the modern". ${ }^{12}$ Similarly, she carries out swimming and vacationing, which are parts of a modern lifestyle, with haşema (a full body suit designed to let women and men swim without having to uncover the parts of their bodies which are religiously prohibited from being seen by strangers). In this respect, it would not be wrong to argue that the understanding of modernisation through 'Western values', which has been prevalent in Turkey for about 200 years, has undergone a transformation in terms of form and content through 'Islamic women'. ${ }^{13}$

From the mid-1980s, Islamic groups started to attach special importance to the issue of woman. After the feminist women's movement took to the streets, the 'issue of woman' left its mark on the country's agenda and became the hottest discussion topic in Turkey. The religious woman, who started to take a greater part in social life, naturally started to constitute a new problem area in the Islamic part of society, beyond the headscarf problem in universities. In order to deal with this problem, various magazines were published by Islamic groups. Among the first were Mektup (Letter), which started in 1985, and then Kadin ve aile (Woman and Family), and they reached circulation levels of hundreds of thousands. It is estimated that there were a total of 27 magazines published by Muslim women in the 1990s. ${ }^{14}$

Through these magazines, each Islamic group developed its own understanding of womanhood. Based on the themes covered in these magazines it could be argued that mainly two stances have been developed on the role of women among Islamic groups. The first one attempts to limit women to familial roles, does not lean towards their employment, and considers the quests for women's rights to be unnecessary and even harmful. The other one, on the other hand, tries to present a political and somehow existentialist understanding of women, believing in the self-realisation of women through participation in public life. 


\section{The Transformation of the 'Islamic Woman's' Role}

It is correct to state that the headscarf is a tool to participate in public life and a way of 'existence' for 'Islamic women'. The Kemalist reaction against the headscarf has caused religious groups to unite and to gain dynamism. This dynamism has also brought about several women and groups in the 'Islamic women's' movement to question the traditional role of the Muslim woman. The Muslim woman in the traditional understanding of Islam is a woman whose prominent characteristics are her commitment to her house, her obedience to her husband and her maternity. The woman, in a sense, is surrounded and protected by the man. However, the process of taking part in public life has brought about the chance for women to cease being the passive object beneath or behind a man. The headscarf struggle has rendered the woman the comrade of the man and given her a new role that is embodied in the concept of 'political sister'. It can be argued that the political sisterhood, which denotes positioning beside - not behind - men, constitutes the first step of the path leading to the 'individual woman'.

The individualisation process for 'Islamic women' developed within the struggle against the prohibitive attitude of the state towards the headscarf in the 1980s. Individual cases in the 1960s and 1970s had not yet been able to render the issue a 'nationwide' problem that the state would be interested in. The headscarf issue gained real prominence in the eyes of Islamic groups and the state at the national level following the decision of the Council of Higher Education (Yüksek Ögretim Kurumu, YÖK) in 1982 that prohibited veiled students from attending classes. The headscarf, which then turned into the turban with this decision, started to occupy the agenda of both politics and the media. Although the severity of the decision was moderated following the reactions of students, student demonstrations erupted after entrance to universities was banned in 1984. These demonstrations started in Ankara University's Faculty of Divinity, as was the case in 1968. As the headscarf ban spread to other universities, protests naturally became widespread. Attempts by the political authorities under Turgut Özal to solve the problem through laws were halted by the Council of State, the Constitutional Court, the President or central left parties of the time and the issue became vague. On the other hand, in parallel with the liberalisation in the 1980s, approval and tolerance toward the headscarf became widespread throughout the country. The ambiguous situation on the issue of turban and attitudes differing from one university to another continued until the '28 February period'. ${ }^{15}$

The ' 28 February process' became a serious starting point, and in some sense the breakaway point, for this issue. The ' 28 February period' rendered the headscarf a national problem toward which the state developed a singular attitude. The total war started by the state against the headscarf under the leadership of the YÖK 
administration paved the way for 'Islamic women' to form a movement around this symbol. One of the epicentres of this movement was Istanbul University, which was selected as a model by YÖK. The headscarf ban came to be applied in all departments of Istanbul University in 1998 and female students were enjoined to shed their headscarves through the 'persuasion rooms' set up at the entrance of the university campus. The reaction was swift. The Beyazit Campus of Istanbul University became the centre of the 'headscarf demonstrations'. Female students were at the forefront of most of these demonstrations. However, as with other protest demonstrations, male students, some feminist women, leftist student unions and a number of politicians were present. Support for the demonstrations, which lasted for months with concerts and other activities, increased daily and the attention of the entire country was attracted to the issue. Headscarf demonstrations were not limited to the Beyazit Campus of Istanbul University. Similar protests erupted in almost all cities with universities. 1998, when the '28 February' decisions came into effect, is the year in which 'headscarf demonstrations' took place throughout the country. The protests in some cities were considered by the state as an 'uprising' against the political order and were harshly quelled. ${ }^{16}$

One of the demonstrations initiated at the national level which attracted the attention of the entire country, was launched by medical faculty students in June 1998. About 60 veiled medical students initiated a march from the Cerrahpaşa Faculty of Medicine towards Ankara under the name of the 'White March', with the aim of travelling through the entire country. The demonstrators walked up to Ankara with enormous support from the people living en route. ${ }^{17}$ Following this demonstration, another large-scale protest was staged which attracted the highest popular support throughout the history of the republic. On 11 October 1998, pioneered by various NGOs, the protest aimed at forming a countrywide human chain under the motto 'hand-in-hand for freedom of belief and thought' (inanca saygl, düşünceye özgürlük için el ele). The human chain started in front of the Cerrahpaşa Faculty of Medicine and continued up to the town of Bolu - stretching over nearly $250 \mathrm{~km}$ ! Although the chain was blocked in Bolu by a military unit, it succeeded in reaching up to Van in the east and Hopa in the north of the country. It was the first time in Turkey that millions of people from different locations were gathered simultaneously and formed a human chain of more than 1,000 km without causing any disorder. ${ }^{18}$ This demonstration created a shocking impact on the government, especially on YÖK, and participating officials have subsequently been subjected to legal investigations and prosecutions. ${ }^{19}$

However, despite these large-scale demonstrations and increasing social awareness, the headscarf issue continued to be a critical problem occupying the country's agenda. After the February 28 period, the application initiated in Istanbul University was disseminated into all universities in Turkey and transformed into a 
national politics controlled by YÖK. Students, unable to get the results they expected from street demonstrations and the judicial authorities in Turkey, resorted to the European Court of Human Rights at Strasbourg. Leyla Şahin, who was expelled from Istanbul University Faculty of Medicine due to her headscarf in 1998, also took the issue to Strasbourg. However, the Court decided to justify the practice. While this decision created a shock among Islamic groups, it strengthened the hand of Turkey's Kemalist elites.

It can be said that the headscarf constituted the main focus of the struggle during the '28 February' period. The obdurate stance of the state against the headscarf did not remain limited to universities and was exported to other fields. Schools controlled by the Ministry of National Education have been among the places where the ban was executed harshly. Numerous veiled teachers working in schools were eventually dismissed from their jobs. The ban was even attempted to be disseminated into private training centres (dersane). The actors of ' 28 February' have rendered the veil of women an existential issue for the regime. Merve Kavakci who was elected as a member of parliament (wearing a headscarf) stepped on the toe of this hyper-active group. As a result, a 'hunt' was organised. The most dramatic scene of this 'hunt' was the midnight bust by the Chief Public Prosecutor Nusret Demiral, accompanied by a police group and an army of reporters to her house. Kavakci's membership in the parliament was soon terminated and the Virtue Party (Fazilet Partisi, FP), mediating her election as deputy, was closed down by the Constitutional Court. ${ }^{20}$ The constitutional amendment of 2008 made by the currently ruling Justice and Development Party (Adalet ve Kalkinma Partisi, AKP) to make the wearing of the headscarf permissible in universities has made this political party even more popular. The constitutional amendment was invalidated by the Constitutional Court. The Court also punished AKP by ruling to deprive the party of financial assistance from the Treasury.

What kind of impacts does the headscarf issue - occupying the country's agenda for about 50 years, resulting in the hard-line stance of the state - have on Muslim women? Undoubtedly, these impacts have psychological, sociological and political dimensions. It would not be wrong to argue that the political atmosphere that emerged around the headscarf has paved the way for a significant transformation among Muslim women as well as creating traumas. The most significant dimension of this transformation is the fact that women have developed a 'women's movement around the headscarf'. While this women's movement formed by Muslim women strives to overcome the state and its uniform modernisation policy on the one hand, it continuously questions the traditional roles of women, on the other. It should be noted that there exist various lines within the 'Islamic women's' movement, and the end of one of these lines reaches up to feminism. 'Islamic women' who strive to take part in public life turn upside down the traditional religious roles expected 
of them. As Sibel Eraslan puts it, "whereas men want to seclude them and demand from them to be beautiful wives and mothers, they dare to poke their noses into the life". ${ }^{21}$ The awareness and the feelings of self-reliance in women stirred by the struggle to take part in public life have eventually directed them to question their traditional roles.

It is noteworthy to claim that street demonstrations have had multidimensional consequences on Muslim women who tried to be insistent followers of their own decisions. Above all, young girls have been politicised through street protests and built political identities on this foundation. As Sibel Eraslan, who became prominent when she was the head of the Welfare Party's (Refah Partisi, RP) Istanbul Women's Branches, stated: "the organisational daring of the 'Islamic women' in the 90s has become a journey from being sisters and wives to being citizens". ${ }^{22}$ Considering that the 'headscarf demonstrations' required not only a multidimensional background preparation but also courage, it becomes clear how transformative this was for women. This, indeed, points to a revolutionary transformation for the religious women who were expected to become socialised with such characteristics as 'solemnity', 'silence' and 'obedience to men'. Women who took part in the headscarf struggle have directed their interests from housework, obedience to the husband and childcare to the state, political participation, demonstrations, protests, knowledge, information, and so forth. Some have likened this interest to the 1968 generation of leftist movements. Sibel Eraslan stunningly depicts how a new generation, which can be called the ' 98 Generation', has emerged among Muslim women in Turkey:

March 1998: Thousands of youths were protesting in front of the university behind a large red banner on which, written in yellow, were the words "students arm-in-arm, to a general boycott" (ögrrenciler kol kola genel boykota). These were the colours not hitherto used in 'Islamic women's' protests. Some metal and rock bands accompanied them with music. Environmentalist youths were also among the groups supporting the girls. Headscarf demonstrations would go down in the history of the Republic as the women's demonstrations, which attracted large and different groups but remained inconclusive. Veiled women were shouting a slogan, which we had been used to hearing from leftists; "don't be silent! If you do, you will be the next!" (susma sıra sana gelecek). What has changed from 68 to 98 ? How come these proper little girls (hanım hanımıck) continuously resembled to the image of other militant women? ${ }^{23}$

Street demonstrations have at the same time provided young girls with a personality and a sense of self-realisation. Young girls, who had matured in such protests, have become able to show the courage and self-reliance to continue their educations in various universities in Europe and America alone. It would not be wrong to claim that women who entered into an intense struggle on the headscarf issue have fought for an "identity", "personality" and "existence". ${ }^{24}$ It would not 
be an exaggeration to say that the Muslim woman, by maturing in this struggle, has realised the role of the woman (as characterised in Atif Yilmaz movies), a woman who is able to exist and pursue her own choices without needing her husband's or father's or another man's support. The following expressions strikingly demonstrate how the headscarf ban has rendered an ordinary young girl a militant:

I was unable to associate myself with shouting at the top of my voice in protests. Moreover, I used not to consider marching on streets to be wise. Yet, I no longer had a class to go, or a course to study for [...]. I was at loose end, feeling quite empty, I felt myself dwindling. So dwindled that I fell prey to the wind and suddenly found myself among my friends in Beyazit. At that very moment, little Ayşe began to grow up. Her tears were not sorrowful anymore, they were the tears scattering lights of hope. I was both shouting slogans and marching towards the school I had been expelled from. ${ }^{25}$

The struggle over the headscarf has provided women with maturity, change and transformation; as well as paving the way for great feelings of defeat, disappointment, hatred and anger. ${ }^{26}$ There are many groups towards which such feelings are directed. The most prominent of them is undoubtedly those people acting under the name of Kemalism. It is thought-provoking that Kemalism, which had developed as a modernising and civilising project in the first half of the twentieth century, turned against some women at the end of the second half of it with a narrowed vision and mind. This vision has also become the source of a strong hatred among women involved in Turkey's Islamic movements. The following expressions strikingly reveal what Kemalism is identified with in the eyes of these women:

January 1998: Female students attending universities with headscarves started to be blacklisted by secretaries at doors. The letter ' $T$ ' was put in the place of or near the names of these students. [...] Women were marked only, simply and shortly with the letter ' $T$ '. I liken the letter ' $T$ ' attached to my name to the Zion badge that Anne Frank was obliged to carry. And of course I liken those who attached it to the Nazis [...]. ${ }^{27}$

We can say that the feeling of aversion and hatred found in these sentences contains multidimensional and deep traumas. The 'Nazi' is a figure that constitutes the indelible subconscious of Jewish people today. Kemalism, on the other hand, has become an entity which is considered equal to Nazism at least in the eyes of some people living in Turkey (a group of substantial size, however, when considering the size of the social base) - a comparison which is certainly a bit too farfetched. Nevertheless, it is unfortunate for a society moving towards modernisation that Kemalism, which had constituted an important reference to the salvation and emancipation of women in the first quarter of the twentieth century, has turned into an ideology, an oppressive policy, which is identified with Nazism in the eyes of some other women at the extremist fringe. 
It is observed that many Muslim women involved in Islamic movements are largely disappointed with secular women. Although some feminist women and leftist groups supported them, the deafness of most secular women to the issue has created a deep resentment among them. The feelings expressed by a medical student who had been expelled from the Hacettepe Faculty of Medicine are thoughtprovoking in this sense:

My elder sisters are not veiled and all of us have acquaintances who are not veiled. Due to the prejudiced attitude I experienced in the school, I became timid with all people who are not veiled. I still feel uneasy when I meet somebody. We took up new phobias due to their discriminatory attitudes towards us. ${ }^{28}$

It would not be inaccurate to argue that this attitude has paved the way among 'Islamic women' for a common trauma. Mualla Gülnaz, known as a 'Muslim feminist', states it in the following way: "the women who fought the headscarf struggle feel that they are left alone. They no longer trust the state, nor politicians, nor their families and nor the men they share the same faiths with". ${ }^{29}$ Many women who really suffered from the headscarf issue bear these feelings.

The struggle over the headscarf ban has functioned as a bridge between women from the Islamic movements and some women from other sectors of Turkish society. Some feminist and leftist groups have taken sides from the very beginning with the women who were fighting against the headscarf ban. It would not be wrong to argue that a mutual empathy and an interaction emerged in this process. While some feminists and leftist women supported the headscarf by considering it to be a right and a different way of existence, it can be argued that a sympathy and an interest in their ideas, and a feminist discourse, have gradually emerged among 'Islamic women'. Sibel Eraslan depicts this change and transformation: "The opportunity to know and talk to other women means a more feminine colour and voice among 'Islamic women'". ${ }^{30}$ One can thus argue that the movement called 'Islamic feminism' has flourished on the ground created by this interaction.

\section{Flirting with Feminism or the Advent of 'Islamic Feminism'?}

The concept of 'Islamic feminism' was developed in the 1990s by various Iranian and Arabic academics and writers. ${ }^{31}$ Academics and writers like Asaneh Najmabadeh, Haleh Afshar and Mai Yamani have used this concept in their studies, but the concept eventually started to be used by other academics and writers in various countries. One of them is the Egyptian author Aziza M. Karam. According to her, everyone who thinks that women occupy a secondary position due to their sex/gender and who make efforts to develop egalitarian and fair gender relationships are feminists. 
Karam, departing from this common feminist definition, draws attention to the difference between 'secular feminism' and 'Islamic feminism' in Egypt. ${ }^{32}$

Those who advocate 'Islamic feminism' centre all of their claims on the Qur'ān. Their main thesis is as follows: the Qur'ân used the symbols and language of the patriarchal Arabic culture. The messages in the Qur'ān are naturally expressed within the form of this language. Only the Prophet can grasp the real spirit of the Qur'ān, which is a universal and eternal source. If the message and cause of the Qur'ān is universal, then we should not read it as a given text with a uniform definition. Naturally, the Qur'ān could be perceived differently in different historical circumstances, different social environments and different languages and cultures. In this respect, the spirit and message of the Qur'ān can be interpreted in different ways within a certain context. ${ }^{33}$

Does 'Islamic feminism' have an equivalent in Turkey? Or how do the groups of women who drive the women's movement in Turkey approach 'Islamic feminism'? Prominent researchers and writers in the 'Islamic women's' movement like Cihan Aktaş, Yıldız Ramazanoğlu, Nazife Şişman, Mualla Gülnaz, Hidayet Ş. Tuksal, Fatma K. Barbarosoğlu, Sibel Eraslan, Ayşe Böhürler and Nihal Bengisu Karaca prefer to stand aloof from the identity of 'feminism' ${ }^{34}$ It can be argued that the main reason lying behind the distant stance of 'Islamic women' from the feminist identity is the belief that feminism is identified with enmity against man, unlimited sexual freedom and a movement that attacks the family. A woman, in an article for Aksiyon magazine wrote the following, articulating the common concern of numerous 'Islamic women':

The author of the following sentences is very anxious while writing that they would contain the word 'feminism' abundantly; "worst than the nightmares in dark nights having being labelled with a feminist identity [...]." Who can say that we are possessed by an unjustifiable anxiety while feminism means enmity to man, deviation, shrewdness, spinsterhood and even ugliness? Today, most veiled bluestocking women who define themselves as 'pious' approach the word 'feminism' with the same hesitation. While some get all tuckered out trying to get rid of this intrusive trouble, some others challenge the use of the term as a method of punishment; "I am a feminist, so what!"35

The perception of women in the Islamic movements of feminism is not limited to this. The fact that the majority of women in the feminist movement did not support 'headscarf victims' and that they even did not support the headscarf as a women's right has paved the way for the feminist movement to be viewed by 'Islamic women' as a Kemalist/elitist movement. Yenişafak newspaper columnist Özlem Albayrak labelled feminism as "a movement in the monopoly of a few modern and brand-loyal women of Nisantaşı". ${ }^{36}$ Albayrak, in the same interview, stated "if I believed in the objectivity and truthfulness of the feminism in Turkey, I'd become a feminist". ${ }^{37}$ The 
number of those women who are sympathetic to feminism but avoid being identified with it is very high among 'Islamic women'. The reason lying behind this is not only the abovementioned image of feminism but also the fact that 'Islamic women' see the problems of women from a perspective different from that of feminists. Ayşe Böhürler articulates the common opinion of many 'Islamic women' writers as follows: "I define myself as a person who advocates women's rights but who is not a feminist." ${ }^{\prime 3}$

Some Muslim women are of the opinion that the concept of Islamic feminism is intentionally imposed from outside and it is a part of the project of creating a moderate understanding of Islam. Nazife Şişman, who translated Amina Wadud Muhsin's book Qur'an and Woman ${ }^{39}$ and who became notorious for the mixed-gender Friday prayers she led, indicates that she considers the idea of 'reinterpretation' that she used to appreciate to be dangerous for today. Şişman states that she views the re-interpretation of Islam "both as an outcome of an imposition and as an attempt to destroy the religious base that is the basic foundation of the Islamic world". ${ }^{40}$ Based on this understanding, Şişman wrote a book entitled Globalisation's Grip, Islam's Veil and argues that orientalism imposes a new understanding on the Islamic world through women. According to Şişman, the modernisation or reformation in religion that includes the reinterpretation of Islam from the perspective of women has occurred within a hegemonic relationship with the West from its very beginning. ${ }^{41}$

In a similar fashion, Sibel Eraslan, who argues that the terms Islam and feminism are in contradiction with each other, asserts that the conception of 'Islamic feminism' is a part of the attempts to modernise the third world countries through women's bodies. ${ }^{42}$ Yıldız Ramazanoğlu, who is notable among 'Islamic women' with her works in literature, shares this opinion but she points to another problem that the attempts of the West to reconcile Islam and feminism will generate: the risk of Muslims to avoid advancing toward the problems experienced by Muslim women so as not to be subjected to accusations of 'they serve the purposes of the West'. It seems that most 'Islamic women' pay special attention to stay away from feminism due to the fear of appearing to be serving for the West. When one considers the facts that the Islamic subconscious in Turkey is anti-Western in character, then one sees how difficult it is for these women to be identified with a feminism originated in the West.

The group that has frequently been shown as an authority in debates on Islamic feminism in Turkey is Ankara Capital City Women's Platform. One of the founders of the Platform, Zehra Reçber, gives the message that they do not fully reject feminism by stating "our feminism is a self-appointed feminism, we do not believe that we have to accept the entire feminist discourse". ${ }^{43}$ Similarly, the Safiye Özdemir says, "we criticise the male-dominated discourse and structure, we question gender roles. But religion is important for us. Our view of family and sexuality is different 
from that of feminism. I define myself as a pious defender of women's rights." ${ }^{\prime 4}$ As is seen in these expressions, the point that detaches both the Capital City Women's Platform and many 'Islamic women' from feminism is centred on the issue of the view of family and sexuality. Although they defend women's rights on the basis of equality by criticising the traditional religious values, women who are defined as 'Islamic feminists' attach a great deal of importance to the family and they advocate the idea that women should experience their sexuality within the limits defined by Islam. Hidayet Ş. Tuksal, whose name has been identified with 'Islamic feminism' per se, explains the distance between them and feminism in an interview as follows:

I have a feminine perspective when considered in terms of the basics of feminism; because I have read a lot, and once you get that perspective it becomes very difficult to unlearn it. However, there emerged a discourse within feminism that is discriminatory, that excludes and ignores men, and even aims to create a separate world free from men. I do not consider this attitude reasonable. We have to live with our fathers, husbands and sons anyway. But I believe that it is necessary to have a feminine perspective in order to be able to correctly understand the existing systems, practices and the religion. In brief, I am a person who aims to interpret what is going on from the point of view of a woman. ${ }^{45}$

It would not be wrong to assert that 'Islamic women' could not resist the gravitational field of feminism, even though they carefully point to their distance from feminism and to points of differentiation. It is observed that they everincreasingly use the jargon, language, concepts and even the perspectives used by feminists. It should not be forgotten that the "interpretation from the point of view of a woman" underlined above by Tuksal is a feminist jargon. This jargon is today used by many 'Islamic women'. The use of the feminist jargon by 'Islamic women' is not limited only to female writers whose names have been identified with feminism. Numerous Islamic organisations use the language brought by feminism to Turkey in either this or that way. The slogan "we are women, we exist and we are strong" (kadınız, varız, güçlüyüz) used in a booklet prepared by the Women's Branch of FP can be given as a clear example of this. ${ }^{46}$ The name Woman's Identity (Kadin Kimliği) given to a magazine by Islamic groups is also meaningful in that sense.

It is noteworthy to state that many concepts increasingly being used among 'Islamic women', such as woman's identity, consciousness-raising, the woman problem, women's rights, women's human rights, women's point of view, the oppression of women and womanly existence, have been borrowed from feminists. Fatma K. Barbarosoğlu, who is notable amongst 'Islamic women' writers for her successful works in the field of story writing and novels, states that this is a "conscious/deliberate borrowing" ${ }^{47}$ In fact, the meanings attributed to these concepts by 'Islamic women' suggest that this is not a simple borrowing but it points to much deeper ties of influence. 'Islamic women', in truth, were timid of 
feminism when it first appeared. This stemmed mainly from the above-mentioned widespread prejudices/stereotypes about feminism. However, as feminist concern has turned towards the real problems experienced in Turkish society, the walls between these two groups are pulled down and 'Islamic women' have become more familiar with the women's studies literature. One can say that this eventually paves the way for 'Islamic women' to comprehend feminism and even develop deep interactions with it.

\section{Conclusion}

As a concluding remark, it may be observed that the understanding of modernisation through 'Western values', which has been prevalent in Turkey since the establishment of the republican regime in 1923, has undergone a transformation in terms of form and content through 'Islamic women' who started to be visible in the public sphere.

- The 'Islamic women's' movement not only undermined the culture and social pillars of centuries-old tradition but also caused Kemalism, which had been one of the most modernising movements at the turn of the twentieth century, to increasingly assume a conservative and reactionary character based on the idea of a single truth.

- The 'Islamic women's' movement continues to develop an alternative manner of existence and self-realisation through a different and subjective identity and a system of values, against a standardising, assimilative understanding of Kemalist modernisation.

\section{Notes}

1. The duties that must be fulfilled in Islam are divided into two: fard al- 'ayn and fard al-kifäyah. While fard al- 'ayn is the individual duty of everybody, fard al-kifäyah is not incumbent upon everybody and is deemed to be fulfilled if some people perform it in a neighbourhood. Studying science is accepted as fard al- 'ayn for men and women.

2. Fatma Karabıyık Barbarosoğlu, "Başörtülülerin tarihine küçük bir katki”, Yenişafak, 9 February 2001.

3. Fatma Kutluoğlu, "Fevziye Nuroğlu 'Yürüyen Hayrat"” [Interview Fatma Kutluoğlu], Umran 129 (2005), 72.

4. For example, $\dot{I}_{s ̧}$ Bank pursued this policy in its employment decisions; see Ufuk Özdemir, “Türkiye'de kadın kıyafetinde modernleşme süreci ve medyanın etkisi”, available online at http:// www.enfal.de/tes17.htm (accessed on 23 June 2011).

5. Enis Berberoğlu, "Türbanın 30 yıllık yükselişi”, Hürriyet, 10 May 1999.

6. Following President Sunay's statement, Şule Yüksel Şenler sent him a letter stating that "the President should apologise to God and society!" As a result, she was sentenced to nine months in prison. Despite Sunay remitting her after two months, she did not accept it and stayed in prison for the full nine months; see Emre Aköz and Nevzat Atal, "Said Nursi'den Fethullah Gülen'e Nur 
Cemaati”, Sabah, 22 December 2004. This event made Şule Yüksel Şenler a hero in the eyes of Islamic circles.

7. See Demet Tezcan, Bir çığır öyküsü: Şule Yüksel Şenler (Istanbul: Timaş, 2007).

8. These two books are still read in Islamic circles; see Hayrettin Karaman, İslam 'da kadın ve aile (Istanbul: Ensar Neşriyat, 1995) and Bekir Topaloğlu, Íslam 'da kadın (Istanbul: Rağbet Yayınları, 2001).

9. Despite all barriers, imam hatip schools still have a significant function in the schooling of girls. For the report prepared by TESEV see Ruşen Çakır, İrfan Bozan and Balkan Talu, "İmam hatip liseleri: Efsaneler ve gerçekler", TESEV, June 2004, available online at http://www.tesev.org.tr/ UD_OBJS/IH\%20Efsaneler-Gercekler.pdf (accessed on 23 June 2011).

10. European Stability Initiative (ESI) in Berlin published its report on Kayseri in 2005 under the title Islamic Calvinists: Challenge and Conservatism in Central Anatolia and pointed to how a city in Anatolia was included in the process of modernisation through religious-conservative values. The report is available online at http://www.esiweb.org/index.php?lang=en\&id=156\&document_ID=69 (accessed on 23 June 2011).

11. Some Islamic writers go against veiling fashion shows by arguing that privacy becomes a show material. For a discussion on the issue see Fatma Karabıyık Barbarosoğlu, Şov ve mahrem (Istanbul: Timaş, 2006, 2nd ed.), 125-30.

12. See Nilüfer Göle, Modern mahrem: Medeniyet ve örtünme (Istanbul: Metis, 2004, 8th ed.).

13. Nilüfer Göle views the 'Islamic women's' movement as a quest for a modernisation alternative to the standardising understanding of modernisation based on assimilation; see Nilüfer Göle, "Islamism, Feminism and Post-modernism: Women's Movements in Islamic Countries", New Perspectives on Turkey (Fall 1998), 53-70.

14. Sibel Eraslan, "Uğultular... Silüitler", in: Aksu Bora and Asena Güldal (eds), 90 'larda Türkiye'de Feminizm (Istanbul: İletişim, 2002), 252.

15. The ' 28 February' process refers to the intervention of the military into civilian politics through a National Security Council composed of civilian politicians and militaries in 1997. Since its military members were dominant in this structure they mostly pressed their stamp on the decisions taken by the Council. A clear example of this was the decision it took against the imam hatip schools and the headscarf in universities, a decision which eventually give way to the resignation of the religious conservative government under Necmettin Erbakan.

16. One of such protests was made in Malatya but it was harshly penalised and many people were jailed. Ruşen Çakır, Direniş ve itaat: İki iktidar arasında islamcı kadın (Istanbul: Metis, 2000), 84.

17. One of the protesters, a student of the Cerrahpaşa Faculty of Medicine named M.A., told how the local people greeted them with enthusiasm as follows: "We came to Gebze from Tuzla. Again, an enthusiastic crowd welcomed us. They were asking 'Can we hug you?' This time, I was ashamed. I did not think how Anatolia would greet us when I set off. We were heroes in their eyes. I later noticed this and then I was proud of them" (quoted from Nazife Şişman, Başörtüsü mağdurlarından anlatılmamış öyküler (Istanbul: İz Yayıncılık, 2004, 4th ed.), 120-1.

18. According to estimates, around 3 million people supported the demonstration. For detailed information on the demonstration, see Ak-der bülten. Beyaz yürüyüs (Istanbul: Ak-Der, n.d.).

19. One of them was Professor Dursun Odabaş, the Dean of the Faculty of Medicine at Van Yüzüncü Y1l University. He was both dismissed from his job at the university and his professor title was taken away for participation in the demonstration. The court later reversed this decision.

20. Merve Kavakci tells her experiences in detail in her book Başörtüsüz demokrasi: Tarih içinde tarih (Istanbul: Timaş Yayınları, 2004).

21. Eraslan, "Uğultular... Silüetler", 260.

22. Ibid., 255-6.

23. Ibid., 261.

24. For a discussion on the issue, see Nilüfer Göle, "Islam in Public: New Visibilities and New Imaginaries", Public Culture 14, no. 1 (2002), 173-90. 
25. A.Y., a junior student at Cerrahpaşa Faculty of Medicine; quoted by Şişman, Başörtüsü, 67-8.

26. For a book that angrily and execrably tells of the treatment that the author was subjected to when she was a student at Middle East Technical University due to her headscarf, see Zekiye Oğuzhan Demir, Bir başörtüsü̈ günlüğ̈̈ (Istanbul: İz Yayınc1lık, 1998).

27. Eraslan, "Uğultular... Silüetler", 261.

28. Quoted by Yeter Şahin, Bütün Yönleriyle Başörtüsü Sorunu (Istanbul: Mazlum-Der, 1998, extended 2nd ed.), 226-7.

29. Ruşen Çakır, Direniş ve itaat: İki iktidar arasında islamcı kadın (Istanbul: Metis, 2000), 52.

30. Eraslan, "Uğultular... Silüetler", 256.

31. For a study on the issue see Valentine M. Moghadam, "Islamic Feminism and its Discontents: Toward a Resolution of the Debate", Signs: Journal of Women in Culture and Society 27 (2002), $1135-71$.

32. Aziza M. Karam, Women, Islamisms, and the State: Contemporary Feminisms in Egypt (London: Macmillan Press; New York: St Martin's Press, 1998). Another similar classification was made by Margot Badran, see her "Between Secular and Islamic Feminism/s: Reflections on the Middle East and Beyond", Journal of Middle East Women's Studies 1, no. 1 (Winter 2005), 6-28.

33. For an original and detailed study on how the Qur'ān shapes the image of women through the language it uses, see Hafsa Fidan, Kur'anda kadın imgesi (Ankara: Vadi Yayınları, 2006).

34. Along with these names appearing frequently in the media, numerous other female researchers and writers have emerged in Islamic circles.

35. Ülkü Özel Akagündüz, "İslami feminizm: Adı var kendi yok", Aksiyon 587 (March 2006), 24.

36. Nişantaşi is known as the centre of upper-class and high-society Istanbul.

37. Metin Sever, Türban ve kariyer (Istanbul: Timaş, 2004), 37 (interview).

38. Ibid., 152.

39. See Amine Vedud-Muhsin, Kur'an ve kadın, transl. Nazife Şişman (İstanbul: İz Yayıncılık, 1997, 2nd ed.).

40. Nazife Şişman, Küreselleşmenin pençesi islam 'ın peçesi (Istanbul: Küre Yayınları, 2005), 94.

41. Ibid., 93-4.

42. Akagündüz, "İslami feminism", 25.

43. Fadime Özkan, "Muhafazakar kesimde kadınlar artık hareketli" (interview).

44. Ibid.

45. Çakır, Direniş, 28 (interview).

46. Şişman, Kamusal alanda başörtülüler (Istanbul: Timaş, 2004), 162.

47. Ibid., 151. 